\title{
International Committee on Systematic Bacteriology Subcommittee on the Taxonomy of Staphylococci and Micrococci
}

\author{
Minutes of the Meeting, 6 and 11 August 1982, Boston, Massachusetts
}

Session 1. Closed meeting

Minute 1. Call to order. The Chairman, R. L. Hill, called the closed meeting to order at 20:00 on 6 August 1982 .

Minute 2. Record of attendance. The members present were L. R. Hill, (Chairman), M. Kocur, (Secretary), A. Torres Pereira, and K. H. Schleifer, D. A. A. Mossel, who was unable to attend, sent a representative, N. Skovgaard. Apologies for absence were received from A. C. BairdParker, J. B. Evans, W. E. Kloos, V. Hájek, and P. Oeding.

Minute 3. Minutes of the previous meeting. The minutes of the meeting held in Munich, Federal Republic of Germany, on 4 and 5 September 1978 were approved.

Minute 4. Past activities. The activities of the Subcommittee since the last International Congress were reviewed by the Chairman. The Subcommittee was relatively active.

Minute 5. Changes in officers and membership. L. R. Hill resigned as Chairman but remains a member of the Subcommittee. K. H. Schleifer was appointed Chairman, and $\mathbf{M}$. Kocur was reelected Secretary of the Subcommittee. The Subcommittee accepted with great regret the resignations of A. C. Baird-Parker and P. Oeding, who had been members of the Subcommittee since its formation. E. Stackebrandt and J. Fleurette were proposed to fill vacancies on the Subcommittee. Some experts on Streptococcus will be invited to join the Subcommittee.

Minute 6. Reorganization of the Subcommittee. There was a discussion about the exclusion of the micrococci from the Subcommittee. The members present voted unanimously for exclusion and for transfer of the micrococci to the Subcommittee on Corynebacterium and Coryneform Bacteria. The results of recent phylogenetic studies, in particular comparisons of $16 \mathrm{~S}$ ribosomal ribonucleic acid sequences, clearly indicate that the micrococci are more closely related to the coryneform bacteria than to the staphylococci. On the other hand, the staphylococci are more closely related to the bacilli and streptococci. Therefore, the majority of the Subcommittee members present were in favor of including the streptococci (the Subcommittee on Streptococci has been disbanded) instead of the micrococci.

Minute 7. Scientific matters. A. Torres Pereira presented some preliminary evidence to individualize Staphylococcus saprophyticus among the novobiocin-resistant, coagulasenegative staphylococci. A common agglutinogen responsible for strong and immediate agglutination against an absorbed serum was found in $S$. saprophyticus strains but not in Staphylococcus cohnii or Staphylococcus xylosus. K. H. Schleifer informed the members of the latest achievements in the classification of staphylococci and micrococci.

Minute 8. Minimal standards for adequate description of new species of Staphylococcus and Streptococcus. The Secretary reported that despite repeated requests no action has been taken on preparing a list of minimal standards. The publication of standards is urgently needed, and some members of the Subcommittee will be requested to compile them.

Minute 9. Current membership. The current membership of the Subcommittee is as follows: K. H. Schleifer (Chairman), Munich, Federal Republic of Germany; M. Kocur (Secretary), Brno, Czechoslovakia; J. B. Evans, United States; J. Fleurette, France; V. Hájek, Czechoslovakia; L. R. Hill, United Kingdom; W. E. Kloos, United States; D. A. A. Mossel, The Netherlands; A. Torres Pereira, Portugal; and E. Stackebrandt, Federal Republic of Germany.

The meeting was adjourned at 22:30 on 6 August.

Session 2. Open meeting

Minute 10. Call to order. The open meeting was called to order by the Secretary, M. Kocur, at 14:00 on 11 August 1982.

Minute 11. Record of attendance. The members present were K. H. Schleifer (Chairman), M. Kocur (Secretary), and A. Torres Pereira. Approximately 20 guests were welcomed. K. H. Schleifer gave a general report on the activities of the Subcommittee and explained the reason for its reorganization. The current view of the classification of staphylococci and micrococci was discussed.

Minute 12. Next meeting. It was agreed that the next meeting of the Subcommittee will be held at the XVth International Congress of Microbiology, to be held in Manchester, United Kingdom, 1986.

The meeting was adjourned at 15:30 on 11 August.

\section{K. H. SCHLEIFER, Chairman} M. KOCUR, Secretary 